studied. Taken by Mr. F. W. Nunenmacher in July from the blossoms of an undetermined species of plant.

Hirsutus approaches oblongus Casey from Utah. It cannot be the same. In the latter the apical angles are acute, pronotum finely punctate, frontal impressions pronounced, legs pale rufo-ferruginous, sides of the pronotum extremely feebly arcuate from base to apex. In hirsutus the epipleura are inflexed apically and it therefore agrees with ursinus Casey. The specimens of hirsutus before me constitute a very homomorphic series and vary only in size.

\title{
NOTES ON THE LIFE-HISTORY OF PACHYPSYLLA CELTIDIS-GEMMA RILEY.
}

\author{
BY HARRY B. WEISS, \\ New Brunswick, N.J.
}

This species, which was described by Riley in 1884 (Proc. Biol. Soc. Wash: II, p. 74) is locally common in New Jersey, the nymphs forming galls on the twigs of hackberry (Celtis occidentalis). These polythalamous galls are deformations of the young buds. They are variable in size and irregular in shape but always bud-like or subglobular and appearing as if formed by a conglomeration of small nodules. Van Duzee (Cat. of Hemiptera, 1917) lists it as occurring in New Jersey, New York, D.C., Va., Ia., Mo., La. and Texas.

The galls are always formed on the new wood and in severe infestations almost every bud is deformed. Each swelling contains from 1 to many cells each of which harbours a nymph. A gall $2 \mathrm{~mm}$. in diameter was found to consist of 1 cell; one of $5 \mathrm{~mm}$. contained 7 cells; one of $8 \mathrm{~mm}$. had 19 cells; one of $9 \mathrm{~mm}$. contained 24 cells and another of $10 \mathrm{~mm}$. had 22 cells. These cells are grouped so that each has a part of the outside wall of the gall covering it. The cells are irregularly oval to subcircular in shape and vary considerably, depending on the sizes of the nymphs occupying them. Galls containing only a few nymphs appeared to have relatively larger cells.

Overwintering takes place in the last nymphal stage, these nymphs emerging through somewhat irregular to regular elliptical openings in the wall of the gall during the last few days of May and the first half of June. These nymphs crawl on the tops of the galls and to the twigs and adults emerge shortly afterward. During the first two weeks of June at Riverton, N. J., where most of the observations were made, adults were plentiful on the stems and leaves of hackberry. Feeding appears to take place chiefly on the petioles of the leaves and on the tender stems, the adults resting head downward. Copulation and egg deposition occur shortly after emergence. Females reared in a.cage deposited eggs before taking any other nourishment except that afforded by the dry stems, which was apparently next to nothing. The eggs are deposited on their sides on the lower leaf surface close to a vein or in the angle formed by two veins. Sometimes they are found on the developing shoots or in crevices around the bases of leaf petioles. They are held fast to the leaf or other surface by means of a short backward projecting stipe, arising near the basal end, which is inserted in the tissue. The basal part of the leaf, where the pubescence in the vein angles is thick appears to be a favoured place for eggs. Many eggs are deposited singly and many in groups ranging from 2 to 8 or 10 .

January, 1921 
It is not known how long it takes for the eggs to hatch. First stage nymphs were not found in the buds until July 20. At this time the buds were not appreciably deformed. From this it appears that over two weeks are necessary. After hatching the nymphs make their way to the small developing buds, crawling between the folded parts and locating in a spot between the centre and the outside of the bud. At first the young nymph is somewhat greenish, but later assumes a yellowish tinge. On September 1, or over a month later an examination of numerous well-defined galls showed nymphs in all stages of growth except the first and the last stages. By the middle and last of September many last stage nymphs were found.

The cells containing the nymphs appeared to be unevenly and thinly lined with a white cottony material. This material increased in bulk as the last stage was approached, and cells containing nymphs of this stage usually had quite a pad of material on that part of the cell directly over the back of the nymph. The hairs on the dorsal part of the body also were covered with the cottony down.

The nymphs collected during the season were easily arrangeable into 5 stages based on their size, but the exact number of instars is not known, due to the difficulty of keeping the same nymph under observation throughout the season. Brief descriptions showing development of the nymphs, are given below. The bodies of the nymphs of all stages are capable of considerable distension, and specimens showing the same dimensions of the head and wing parts vary greatly in the sizes of their bodies, due no doubt to the amount of food in them at a given time.

In addition to the references to this species which are given in Van Duzee's Catalogue, the following one may be noted-Felt., Key to American Insect Galls, N. Y. State Mus. Bull. 200, 1917 (1918), p. 23, fig. 127.

Egg.-Length $0.3 \mathrm{~mm}$. Width $0.1 \mathrm{~mm}$.

Pearly white, smooth, elongate sub-pyriform, rounded at basal end and tapering to acute point at opposite end which bears a fine hair about $1 / 3$ as long as the egg. Widest across basal third. A short, backward projecting stipe arises from near the basal end.

First nymphal stage. Length $0.3 \mathrm{~mm}$. Width of head between eyes $0.1 \mathrm{~mm}$.

Colour lemon yellow; oval, broadest across thorax, abdomen tapering slightly; body flat dorsally or slightly convex, segmentation indistinct. Antennæ whitish, short, projecting; eyes red; median dorsal light line running through head and thoracic segments. Dorsal surface of head evenly and lightly browned, posterior to this area are 2 transverse light brown bands on the thorax and posterior to these bands are many fine transverse brown lines on the abdomen. Lateral edges of abdominal segments bearing minute spines; last abdominal segment terminated dorsally by a comparatively larger spine. Dorsal body surface bearing several fine, short, erect hairs. Outer surfaces of legs lightly browned. Ventral surface lemon yellow. Rostrum extending to second pair of legs, lancets $1 \frac{1}{2}$ to 2 times length of body.

Second nymphal stage. Length $0.4 \mathrm{~mm}$. to $0.55 \mathrm{~mm}$. Width of head between eye $0.18 \mathrm{~mm}$.

Yellowish, broadest across thorax. Somewhat similar to first stage except that the dorsal brown markings are faint or absent; anterior margin of head truncate; sides of thorax arcuate; abdomen more elongate, sides rounded and extrem- 
ity abruptly tapering to point; dorsal hairs more pronounced; abdominal segmentation more distinct. Legs whitish. Sizes of individuals vary greatly. Some specimens suboval in outline, many elongate, some with greatly distended bodies.

Third nymphal stage. Length $0.7 \mathrm{~mm}$. to $0.8 \mathrm{~mm}$. Width of head between eyes $0.26 \mathrm{~mm}$. Form elongate.

Lemon yellow to orange with faint transverse dorsal markings. Antennæ and legs whitish. Thorax subquadrate; sides of abdomen subparallel or strongly arcuate, with pointed tip. Sides of 2 nd and 3 rd thoracic segments slightly produced laterally and somewhat posteriorly. Extremity of abdomen brownish. Segmentation more distinct than in preceeding stage. Extremity of abdomen terminating in 2 minute spines or processes directed upward. Dorsal surface of body es pecially posterior portion of abdomen bearing numerous fine erect hairs.

Fourth nymphal stage. Length $0.91 \mathrm{~mm}$. to $1.34 \mathrm{~mm}$. Width of head between eyes $0.38 \mathrm{~mm}$. Shape somewhat similar to that of preceeding stage.

Somewhat chunky. Colour lemon yellow with faint transverse orange markings. Last 3 abdominal segments closely united and brownish. Antennæ whitish with faint brownish bands. Thorax subquadrate, sides of abdomen strongly arcuate. Insect widest across abdomen. Abdomen flat or subglobular. Wing-pads whitish, much more prominent and larger and strongly directed laterally and slightly posteriorly. Legs whitish, articulations dark. Hairs on head, thorax and abdomen more pronounced, those on abdominal segments long and arranged in transverse rows.

Fifth nymphal stage. Length $1.8 \mathrm{~mm}$. to $2.3 \mathrm{~mm}$. Width of head between eyes $0.6 \mathrm{~mm}$. to $0.7 \mathrm{~mm}$. General colour yellowish with faint orange to red transverse markings. Wing pads, legs, last three abdominal segments brownish. Antennæ sparsely hairy, about as long as width of head and banded alternately with white and brown. Eyes prominent, lateral, red. Head transverse with an irregular brown spot on dorsal surface either side of middle. Thorax subquadrate in distended specimens. Wing-pads of meso- and metathorax extending posteriorly to second abdominal segment. Abdomen subglobular, sides strongly arcuate. Body widest across abdomen. Abdomen consisting of 8 segments, last 3 strongly chitinized, dark brown, terminating in a point; abdominal segmentation pronounced, except in last 3 segments which appear to be somewhat fused. Abdominal segments 6,7 and 8 , especially 7 and 8 , bearing numerous minute tubercles each bearing a hair. Anal segment consists of a horny process bearing minute teeth or tubercles at its base. Dorsal surface of body, especially posterior part of abdomen, bearing fine white hairs. Legs brownish, light on ventral surfaces. Tibiæ bearing several minute spines and hairs. Ventral surfaces of thorax and abdomen yellowish or yellowish red except for several pairs of median, brownish abdominal spots and the dark markings of last three segments. Rostrum extending to between 1st and 2nd pairs of legs, tip dark.

During the last of May and first part of June the dorsal surface becomes bluish green with orange to red markings. Together with the dark areas, this gives a very attractive appearance to the nymph. The abdomen swells, becomes circular in outline, and the narrowest part of the body is across the 1st abdominal segment. The first 5 abdominal segments become bulged and slight tubercular processes appear on the sides. Many of the specimens measure $3 \mathrm{~mm}$. in length and $1.8 \mathrm{~mm}$. across abdomen at this time. 